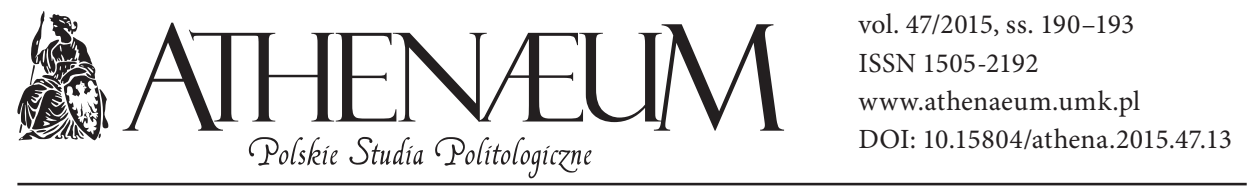

\title{
Інформачійне забезпечення транскордонного співробітництва України: практичні аспекти, red. А.М. Митко, Вежа-друк, Луцьк 2014, ss. 288*
}

\author{
Maryana Prokop**
}

Zachodzące obecnie procesy globalizacji mają zasadniczy wpływ na kształtowanie polityki państwowej, zarówno w jej wymiarze zewnętrznym, jak i wewnętrznym poprzez częściowe przeniesienie możliwości budowania międzynarodowych relacji z kompetencji państwa na podmioty samorządu terytorialnego. Jednostki terytorialne państw coraz większą wagę przywiązują do współpracy transgranicznej, regionalnej i międzyregionalnej, które stały się sposobem na aktywizację życia regionów i społeczności, nawiązania szerszej współpracy gospodarczej, podwyższenia konkurencyjności oraz atrakcyjności regionów.

W Europie Zachodniej za początek intensyfikacji międzynarodowego dialogu na

* Informacijne zabezpeczennja transkordonnogo spiwrobitnyctwa Ukrajiny: praktychnyj aspekt, red. A. Mytko, Łuck 2014, ss. 288.

** Uniwersytet Mikołaja Kopernika w Toruniu, Wydział Politologii i Studiów Międzynarodowych. poziomie lokalnym należy uznać pierwszą połowę XX wieku, celem pierwszych kontaktów było m.in. wzmocnienie pokoju, złagodzenie skutków wojny. Z czasem przerodziły się one w działania na rzecz integracji europejskiej. Natomiast w Europie Środkowo-Wschodniej ten rodzaj współpracy, która stała się platformą do promocji demokracji i wymiany doświadczeń i podobnie jak w Europie Zachodniej służyła przygotowaniu podmiotów do integracji ze strukturami zachodnimi, rozkwitł dopiero w latach osiemdziesiatych $\mathrm{XX}$ wieku ${ }^{1}$.

Współpraca transgraniczna stała się jednym z elementów intensyfikacji integracji europejskiej, przekształcając się w kierunek regionalnej polityki Unii Europejskiej. Obecnie mechanizmy współpracy trans-

1 Zob. K. Hałas, A. Porawski, Twinning - współpraca miast bliźniaczych. Stare wyzwania - nowe szanse, Warszawa 2003; Wspótpraca międzynarodowa samorządu gminnego, red. A. Skorupska, Warszawa 2005. 
granicznej są wykorzystywane się nie tylko w państwach członkowskich UE, ale także jako narzędzie aktywizacji kontaktów z państwami nienależącymi do struktur - między przygranicznymi regionami UE i państwami sąsiadującymi w ramach europejskiej polityki sąsiedztwa.

Geopolityczne zmiany w 1991 roku spowodowały, że Ukraina stanęła przed możliwością kreowania własnej polityki zagranicznej. Jednak brak jasno określonych wymiarów jej realizacji przyniósł trudności z zapewnieniem jej efektywności. Politykę zagraniczną Ukrainy określano (do 2014 roku) mianem polityki wielowektorowości, polegającej na balansowaniu Ukrainy między Wschodem a Zachodem², gdyż skupiała się na tworzeniu przyjaznych relacji z państwami europejskimi przy jednoczesnym budowaniu partnerstwa strategicznego z Rosją. Dochodzi także do intensyfikacji międzynarodowego dialogu jednostek samorządu terytorialnego, geograficzne położenie ( 19 z 25 obwodów Ukrainy jest przygranicznych) sprzyja regionom w nawiązywaniu kontaktów z zagranicznymi partnerami.

Problematykę ukraińskiej polityki transgranicznej, z naciskiem na informacyjny aspekt współpracy, przedstawia praca zbiorowa, która pojawiła się na rynku wy-

2 Zob. J. Bruski, A. Chojnowski, Ukraina, Warszawa 2006, s. 233; T.A. Olszański, Trud niepodległości. Ukraina na przełomie tysiącleci, Kraków 2003, s. 125-127; M. Shmelova, Wielowektorowość w polityce zagranicznej Ukrainy; próba bilansu, „Sprawy Międzynarodowe” 2008, nr 2, s. 31-51. dawniczym Ukrainy. Książka Informacijne zabezpeczennja transkordonnogo spiwrobitnyctwa Ukrajiny: praktychnyj aspekt, pod redakcją Antoniny Mytko to wynik badań badaczy z Wschodnioeuropejskiego Uniwersytetu Narodowego im. Lesi Ukrainki w Łucku. We wstępie publikacji postawiono tezę, że realizacji proeuropejskiego wymiaru ukraińskiej polityki zagranicznej w dużym stopniu sprzyjała współpraca transgraniczna, ponieważ tego rodzaju współpracę przede wszystkim należy traktować jako instrument rozwoju obszarów przygranicznych, a zarazem czynnik realizacji eurointegracyjnych pragnień regionów. Znalazło to potwierdzenie w Państwowej strategii regionalnego rozwoju Ukrainy na okres do 2015 roku $^{3}$ oraz Państwowym programie rozwoju współpracy transgranicznej na lata 2007-20104.

Strukturę i treść recenzowanej książki w pełni oddaje jej tytuł. Praca składa się z wprowadzenia, dwóch rozdziałów i zakończenia. Rozdział pierwszy książki został poświęcony analizie informacyjnego zagwarantowania współpracy transgranicznej Ukrainy z państwami sąsiadującymi: Rosją (J. Tyhomyrowa), Białoru-

3 Постанова від 21 липня 2006 р., Про затвердження Державної стратегії регіонального розвитку на період до 2015 року N 1001, http:// zakon1.rada.gov.ua/laws/show/ 1001-2006-\%D0\%BF, odczyt z dn. 9.02.2015.

4 Державна програма розвитку транскордонного співробітництва на 2007-2010 роки, Урядовий портал, http://www.kmu.gov.ua/control/ uk/ cardnpd?docid=60690971, odczyt z dn. 9.02.2015. 
sią (O. Myronowa), Polską (S. Fedonjuk), Słowacją (M. Najdycz), Węgrami (A. Mytko), Rumunią (N. Karpczuk) oraz Mołdawią (N. Mychaljuk). Czytelnik ma zatem możliwość poznać specyfikę prowadzonej przez Ukrainę polityki zagranicznej, przedstawioną z punktu widzenia ukraińskich badaczy. Przez informacyjne zagwarantowanie współpracy transgranicznej Autorzy rozumieją proces wykorzystania informacyjnych zasobów oraz systemów komunikacji dla optymalizacji współpracy regionów.

Dla polskiego czytelnika najbardziej interesująca wydaje się część dotycząca zarysu polsko-ukraińskiej współpracy transgranicznej. Autor tej części pracy pokusił się o zaprezentowanie: wspólnych działań polskiej i ukraińskiej strony, oceny zadań, które stoją przed podmiotami realizującymi współpracę, oraz możliwości, które ta współpraca daje dla społeczności po obu stronach polsko-ukraińskiej granicy. Efektem owego partnerstwa są działania na rzecz: podniesienia standardów życia mieszkańców, rozwoju gospodarczego regionu, infrastruktury, wymiany kulturowej, wspólnych inicjatyw i programów społecznych, organizacji konferencji, seminariów i spotkań, wymiany doświadczeń, wizyt ekspertów. Autor skupił się także na prognozach problemów i zagrożeń, które mogą mieć zasadniczy wpływ na jego przebieg. Do takich zalicza m.in. asymetrię społeczną i gospodarczą między Polską i Ukrainą oraz różnice $\mathrm{w}$ kompetencjach samorządów terytorialnych państw.
$\mathrm{W}$ rozdziale drugim zatytułowanym Niektóre aspekty realizacji informacyjnego zagwarantowania transgranicznej współpracy Autorzy skupili się na trzech problemach. W pierwszej części rozdziału zaprezentowano transgraniczną współpracę Polski, Ukrainy i Białorusi w ramach euroregionu Bug (B. Juśkiw). Jak zaznacza Autor tej części, współpraca w ramach euroregionu Bug jest doskonałym przykładem pogodzenia regionalnej polityki UE z próbami integracji z ekonomiczno-społeczną i kulturową przestrzenią Unii, państw sąsiadujących z UE. W ramach europejskiej polityki sąsiedztwa współpraca transgraniczna (casus euroregionu Bug) stała się narzędziem pogłębienia komunikacji między przygranicznymi regionami Polski i jej sąsiadami - Ukrainą i Białorusią.

W następnej części analizie poddano współpracę partnerską miast Polski i Ukrainy (O. Bohorodecka). Miasta partnerskie określane są jako miasta bliźniacze, miasta przyjacielskie, siostrzane rozumiane jako równoprawna, długotrwała forma partnerstwa między miastami różnych krajów w celu wymiany kulturowej, gospodarczej i informacyjnej. Do 2011 roku Ukraina nawiązała 879 kontaktów na zasadzie miast partnerskich w sześćdziesięciu krajach świata, w tym najwięcej (183) z Polską. Autorka zaznacza, że intensyfikacja współpracy miast partnerskich Polski i Ukrainy sprzyja niwelacji stereotypowego myślenia obu narodów, promocji i rozwojowi europejskich oraz demokratycznych wartości. Dla dalszej efektywnej współpracy ko- 
nieczne są lokalne inicjatywy z włączeniem do nich mieszkańców miast oraz kształtowanie strategii przyszłej współpracy miast partnerskich.

Rozdział zamyka praca poświęcona interaktywnym zasobom kształtowania politycznej tożsamości przygranicznych społeczności (M. Pikula). Tożsamość polityczna społeczności zamieszkujących regiony przygraniczne $\mathrm{w}$ dużym stopniu kształtuje się za pomocą interaktywnych zasobów, jednakże dla rzetelnego i skutecznego przenoszenia informacji konieczne jest stworzenie internetowych portali, które będą sprzyjać naukowo-kulturowej wymianie społecznej.

Należałoby zwrócić uwagę na najważniejsze konkluzje nasuwające się po lekturze książki. Współpraca transgraniczna może stać się efektywnym narzędziem rozwoju eurointegrancji Ukrainy. Zachodnie przygraniczne regiony Ukrainy czerpią z doświadczeń ich europejskich partne- rów, wdrażając ich normy i wzorce, a tym samym aktywizując procesy integracyjne. Współpracę transgraniczną Ukrainy z państwami sąsiadującymi należy określić jako stabilną oraz skuteczną, gdyż regiony aktywnie wykorzystują różnorodne informacyjne zasoby do optymalizacji współpracy, realizacji postawionych celów oraz informowania społeczności po obu stronach granicy o tym, jak przebiega współpraca.

Praca zbiorowa niewątpliwie jest godna polecenia ze względu na wysoki poziom konceptualizacji i teoretyzowania. Dostarcza wielu szczegółowych, konkretnych informacji o przebiegu współpracy transgranicznej Ukrainy z państwami sąsiadującymi. Za jedyny mankament należałoby uznać brak odniesienia w pracy do polityki zagranicznej państwa poprzez zbadanie, w jakim stopniu efektywna współpraca na poziomie polityki transgranicznej z danym państwem odzwierciedla stosunki bilateralne na poziomie ogólnopaństwowym. 